\title{
Retalhos, Linhas e Agulhas: Compreendendo o Tecido Organizacional e os Desafios de uma Cooperativa de
}

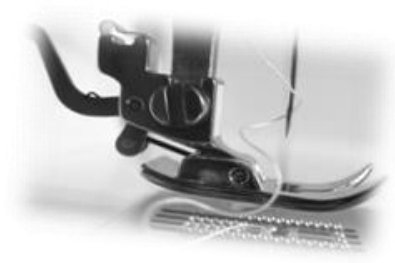

Costureiras

\section{Patchwork, Lines and Needles: Understanding the Social Composition and Organizational Challenges of a Seamstresses Cooperative}

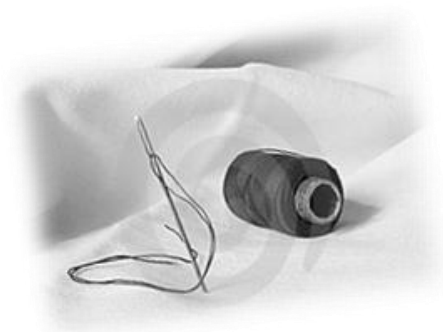

Créditos das figuras: http://vilamulher.terra.com.br e www.comofazer.org.br

Ariádne Scalfoni Rigo

Doutorado em Administração pela Universidade Federal da Bahia (UFBA). Mestre em Administração pela UFPE. Graduação em Administração de Cooperativas pela UFV. Professora da Escola de Administração da Universidade Federal da Bahia e do Programa de Pós-Graduação em Administração (NPGA), Brasil, ariadne.rigo@ufba.br http://lattes.cnpq.br/2648340817180242

\section{Leidimar Cândida dos Santos}

Licenciatura Plena em Pedagogia pela Universidade Federal de Mato Grosso. Graduação em Ciências Contábeis pela Universidade Federal de Mato Grosso, Mestrado em Contabilidade pela Fundação Visconde de Cairu e doutorado em Administração pela UFBA.. Professora adjunta do curso de Administração da Universidade Federal da Bahia, Brasil, leideba@terra.com.br

http://lattes.cnpq.br/8872174949898419

Luciana Carvalho de Mesquita Ferreira

Bacharel em Ciências Econômicas pela Universidade Federal de Minas Gerais, mestre em Administração pela Universidade Federal de Minas Gerais e doutorado em Administração da Rotterdam School of Management. Professora assistente da área de Comportamento Organizacional do Insper, Brasil, lucianacmf@insper.edu.br

http://lattes.cnpq.br/1194661300092581

Resumo: Fruto da ocupação desordenada, uma comunidade no subúrbio de Salvador/BA compartilha diversos problemas sociais e econômicos comuns a estes territórios. Um grupo de costureiras e sua formalização em uma cooperativa é uma dentre tantas iniciativas de buscar melhores condições de vida das populações de baixa renda. No entanto, a constituição da cooperativa, a profissionalização dos membros e a capacitação para gestão, ao longo do processo de Incubação especializado em empreendimentos solidários não se deu sem desafios e erros. Este caso para ensino apresenta a história do grupo de costureiras e do processo de constituição de uma cooperativa. Nele, destacamos algumas especificidades da sua gestão e uma série de eventos que se tornaram críticos ao longo do processo. As possibilidades de análise deste caso são múltiplas, contemplando assuntos como liderança, marketing e aprendizagem organizacional. No entanto, propomos sua análise sobre as iniciativas de intervenção externas em territórios empobrecidos no âmbito da gestão social e da economia solidária. Este processo é comumente designado incubação em economia solidária.

Palavras-chave: Cooperativa, Incubação de Cooperativas, Gestão de Cooperativas.

Abstract: Due to disordered occupation, a low-income community in the suburbs of Salvador, in the state of Bahia, shares many social and economic problems, which are common to these territories. A group of seamstresses and their formalization of a cooperative is one of the many initiatives to search for better living conditions for these low-income population. However, the constitution of the cooperative, the professionalization of members and the capacitation for management, during the intervention by a NGO, were challenging, and many errors occured. This case presents the story of the group of seamstresses and their cooperative. Moreover, some specificities of management and a series of events that have become critical in the process are also present. The possibilities of analysis of this case are multiple, covering issues such as leadership, marketing and organizational learning. However, an analysis of the process of external intervention in impoverished regions from the social management and solidarity economy approaches was proposed. This process is usually designated an incubation in solidarity economy. Key-Words: Cooperative, Incubation of Cooperatives, Cooperative Management.

Texto completo em português: http://www.apgs.ufv.br Full text in Portuguese: http://www.apgs.ufv.br

\section{O tecido: um sonho, um grupo e uma paróquia}

Final do ano de 1997. Em uma das salas da paróquia da comunidade de São Bartolomeu cerca de vinte costureiras, muitas acompanhadas de seus filhos ou netos, faziam acontecer mais um dia de trabalho. Uma delas, D. Laura, 62 anos e costureira de mão cheia, enquanto alinhava uma gola godê, lamenta: "São Bartolomeu, no candomblé, é Oxumaré, o orixá do arco-íris da riqueza". Prossegue: "aqui no subúrbio de Salvador, existiu o Quilombo do

Correspondência/Correspondence: Ariádne Scalfoni Rigo, Universidade Federal da Bahia, Departamento de Sistemas e Processos Gerenciais. Avenida Reitor Miguel Calmon Vale do Canela 40110903 - Salvador, BA - Brasil Telefone: (71) 32837354 ariadne.rigo@ufba.br 
Urubú, lugar em que negros se refugiavam da escravidão praticada por fazendeiros em Pirajá, São João do Cabrito e Paripe. São Bartolomeu não é propriamente um bairro, mas uma região dentro da suburbana, que abriga diversas comunidades. Lugar de luta, de gente que luta. Como eu!" Ana Clara, neta de D. Laura, 10 anos, com os olhos e ouvidos atentos, brincava com dois retroses de linha ao mesmo tempo que prestava atenção nas palavras da avó que vivia a coser "roupas de sair" vendidas aos moradores da comunidade. "Voinha, o que você tá dizendo? São Bartolomeu tem nome de santo, mas é um orixá que dá riqueza?". D. Laura abriu um sorriso e respondeu: "deixe, Clara, deixe. Estou só lembrando que aqui é lugar de sonhos e de lutas; dos santos e dos orixás. E rogo a eles, não importa se santo ou orixá, que um dia cesse este sofrimento de trabalhar demais, de sol a sol, em troca de trocados minguados. Meu sonho, minha querida, é que um dia este grupo de costureiras possa ganhar melhor e ter condições de se sustentar".

D. Laura, do alto dos seus 62 anos de idade, enquanto falava para a sua neta sobre os santos e orixás, dos sonhos e das lutas e lamentava suas próprias dificuldades parecia antever o futuro próximo das mulheres costureiras. Moradora de São Bartolomeu, umas das comunidades que compõem o chamado Subúrbio Ferroviário de Salvador, D. Laura vivenciava as agruras de dias sem muitas perspectivas de melhoria de vida. Era costureira e junto com outras dezenove mulheres, fabricavam o que chamavam de "modinha", que era vendida por sacoleiras na própria comunidade. Nas palavras de uma delas, "elas mesmo cortavam, elas mesmo costuravam, elas mesmo produziam e elas mesmo, às vezes, saiam pra vender. Colocavam na sacola e saiam".

A comunidade São Bartolomeu, na década de 1990, guardava as mesmas características dos dias atuais. Assim como na época, é um lugar de situação precária, assim como outros territórios da cidade de Salvador. O seu surgimento foi propiciado pelo crescimento urbano da capital baiana, principalmente por causa da expansão do capital imobiliário (em articulação com o poder público) e pelos fluxos migratórios vindos do interior do estado. A ocupação desordenada e informal do Subúrbio Ferroviário deu origem a várias comunidades que compartilham problemas decorrentes da informalidade, desemprego e precariedade de infraestrutura urbana. Muitos dos seus moradores se mudaram do interior da Bahia, e até mesmo vieram de outros estados para a capital soteropolitana em busca de melhoria de vida, mas se depararam com o desemprego e dentre outras dificuldades socioeconômicas.

Os moradores da comunidade de São Bartolomeu pertencem majoritariamente às classes sociais $D$ e $E$. De etnia afrodescendente, os moradores normalmente sofrem com problemas de natureza étnico-racial. Além disso, há muitos adultos desempregados. $\mathrm{O}$ índice de desemprego na comunidade ultrapassa $20 \%$, acima da média registrada na cidade de Salvador. Os números pertinentes à escolaridade indicam que apenas $10 \%$ da população da comunidade, com idade compreendida na faixa etária de 21 a 60 anos, concluiu o ensino médio. Indicam também que $60 \%$ desta população cursaram apenas os primeiros quatro anos do ensino fundamental (antigo primário). Apesar de não constar na lista das comunidades mais violentas da cidade, São Bartolomeu é uma comunidade que registra altos índices de violência (Pangea, 2005).

Naquelas vinte mulheres costureiras se reflete a realidade da comunidade. Apenas cinco cursaram o ensino médio e a maioria não conseguiu ir além da quarta série do ensino fundamental. Dezessete mulheres são mães, com um a cinco filhos. Oito delas são solteiras, viúvas ou divorciadas e chefiam suas famílias, sendo responsáveis pelo total sustento dos seus lares. A maioria absoluta das mulheres nunca teve oportunidade de participação formal na atividade econômica tendo exercido profissionalmente, ao longo da vida, apenas atividades informais ou 'bicos' (Pangea, 2005). Vê-se que se trata de um grupo de pessoas com baixa capacitação e afirmação social. Porém, as vinte mulheres de São Bartolomeu, com os instrumentos que obtiveram com a ajuda do Padre Tito, vigário da igreja do bairro, trabalhavam muito e tentavam levar adiante o projeto "Costureiras", que tinha a finalidade de contribuir para que as donas de casa pudessem obter renda através do próprio esforço e sustentar a família. O grupo de mulheres mantinha uma pequena produção no salão paroquial da igreja católica local.

$\mathrm{Na}$ época, em meados de 1997, embora as mulheres costureiras fossem um grupo, ainda não haviam sido formalmente organizadas; ou seja, não se tratava de uma entidade jurídica, legalmente constituída. O pároco havia decidido colocar em prática um projeto social para ajudar algumas donas de casa a terem alguma renda mensal e teve a ideia de apoiar um grupo de costureiras. Por meio de doações, ele conseguiu algumas máquinas de costura simples, um pequeno incentivo financeiro para o início do negócio, alguns móveis e um curso de corte e costura ministrado gratuitamente pelo SENAI soteropolitano. D. Laura, dentre todas as mulheres do grupo, era a única que exercia o ofício de costura há mais de cinco anos e, portanto, tinha experiência profissional anterior a formação do grupo. Ela tinha o domínio tanto da técnica do corte, quanto da costura.

Assim, usufruindo do apoio do pároco, as mulheres aderiram ao projeto e passaram a trabalhar juntas. A produção era escoada na própria comunidade. Os moradores poderiam fazer compras diretamente no salão paroquial ou, indiretamente, comprando das sacoleiras que vendiam as roupas em troca de um pequeno percentual. $O$ grupo de mulheres trabalhava quase que de forma voluntária. Não havia qualquer organização da gestão, dos custos, das compras, do pessoal. Mal faziam o controle das compras de matérias-primas, das roupas entregues para as sacoleiras e dos gastos com a manutenção das máquinas de costura. Rigor maior tinham somente com o rendimento obtido das vendas e com a divisão, por igual, do que sobrava após pagarem todas as contas. D. Laura e o pároco atuavam como líderes do grupo e se encarregavam das tarefas burocráticas do dia-a-dia, como a aquisição de tecidos, linhas, tesouras, constituição de parcerias com vendedoras etc. 
O faturamento bruto mensal dificilmente passava de $R \$ 7.000,00$ (sete mil reais). Deste montante, o grupo de mulheres tirava todos os custos envolvidos na produção e venda das roupas confeccionadas. O que sobrava, cerca de $\mathrm{R} \$ 2.000,00$ (dois mil reais) era dividido em partes iguais entre as costureiras. Isso representava $R \$ 120,00$ (cento e vinte reais), menos do que o valor do salário mínimo da época. Uma parte do faturamento líquido as mulheres repassavam para a paróquia para ajudar na manutenção das atividades religiosas e do próprio espaço que ocupavam. Delas o pároco não cobrava aluguel, energia elétrica e nem água. D. Laura e as costureiras partilhavam, ao final, os trocados com os qual ajudavam a manter suas famílias.

$\mathrm{Na}$ comunidade de São Bartolomeu D. Laura era reconhecida não só como uma competente costureira, mas também como líder das mulheres costureiras. Não foram raras as vezes em que ela se viu diante dos conflitos vivenciados pelas mulheres, seja dentro do próprio lar (vitimadas por maridos agressivos) ou na sociedade (sofrendo preconceito de gênero, raça e condição social). Com seu jeito calmo e sempre solidário, D. Laura era uma espécie de amiga com maior experiência e, por isso, chamada a todo instante para resolver conflitos e aconselhar suas companheiras, como ela mesma gostava de se referir as mulheres da comunidade.

\section{O corte: alguns sonhos, pequenos grupos e outros atores}

O ano de 1998 começou e o sonho de D. Laura e das demais costureiras começou a se realizar. Neste mesmo ano, uma Organização Não Governamental (ONG), centrada em desenvolvimento territorial, em parceria com o poder público municipal, resolveu desenvolver, em comunidades de Salvador, iniciativas que propiciassem a compreensão, por parte de grupos que tinham pequenos negócios estabelecidos, do conceito e funcionamento do cooperativismo. Essa iniciativa permitiu às costureiras pensarem na ampliação da pequena produção que vinham mantendo com o apoio da igreja católica. E foi com essa esperança que o grupo de costureiras participou desta iniciativa de capacitação implantada pela ONG, na comunidade de São Bartolomeu.

A iniciativa contemplou um aprendizado que permitiu às costureiras uma primeira noção de que poderiam criar uma entidade comercial independente e, quem sabe, aumentar os ganhos. Advindas daí, dessa primeira etapa de educação cooperativista, até o final do ano de 2000, outras ações também voltadas para o estímulo da criação de pequenos negócios e melhoria da renda foram implementadas na comunidade. Nesta época, até mesmo um Plano de Negócios foi criado para tentar alavancar os ganhos do grupo de costureiras. Porém, sua implantação não foi possível em função de dificuldades como: falta de recursos, de qualificação profissional, redução do tamanho do grupo, dificuldade de escoar a produção, falta de recursos para adquirir máquinas e equipamentos, dentre outras.
Entre os anos de 1998 e 2000, embora o grupo tivesse participado de iniciativas de formação de uma cooperativa, as condições financeiras, de produção e de infra-estrutura continuavam as mesmas. D. Laura continuava sendo uma líder e quinze costureiras permaneciam no grupo. Neste período, algumas mudanças ocorreram e as costureiras, embora sempre tivessem enfrentado dificuldades, se reinventavam e buscavam alternativas.

As costureiras mantiveram-se no espaço da igreja, mas já não produziam somente modinha. Em função da queda nas vendas, foram em busca de parcerias com empresas da cidade e passaram a costurar também, e sob encomenda, roupas de cama para hotéis e fardamentos. Embora tivessem diversificado as atividades, a gestão do grupo continuava do mesmo jeito: feita de forma totalmente intuitiva, com D. Laura à frente de tudo.

Também neste período outras dificuldades surgiram que se somaram as anteriores. Uma delas foram os conflitos surgidos dentro do grupo em função dos baixos ganhos mensais. As mulheres precisavam ganhar melhor e, para algumas delas, a alternativa foi buscar emprego no mercado de trabalho agora que sabiam costurar Durante algum tempo o grupo contou com menos de dez costureiras. Outra dificuldade se relacionou com a decisão da paróquia em rever o apoio ao projeto inicial, somando-se a isso o próprio interesse do grupo remanescente de costureiras em buscar a sua independência produtiva.

Todo este conjunto de acontecimentos combinou-se com a vontade da líder, manifestada como um lamento para sua neta no ano de 1997, de aumentar a capacidade produtiva das costureiras e aumentar os ganhos mensais. Motivada pela atuação da ONG na comunidade, com o espírito cheio de energia, D. Laura e o seu grupo de colegas aceitou a parceria com a incubadora do negócio. A ONG tinha total interesse em fomentar (com apoio financeiro e profissionalização) grupos já constituídos na comunidade de São Bartolomeu e o das costureiras foi um dos contemplados.

Enfim, no ano de 2001, a ONG formulou o projeto de criação da Cooperativa das Costureiras do Subúrbio Ferroviário de Salvador e buscou captar os recursos financeiros necessários para alavancar o negócio. A boa notícia chegou em 2002. A ONG havia elaborado dois projetos diferentes para o grupo de costureiras. Um para criar a cooperativa, em 2002, e outro para consolidá-la, em 2005. Estes dois projetos foram aprovados e financiados por três instituições privadas diferentes. No primeiro momento, o de criação, o foco se deu na constituição do grupo (até então era de menos de dez mulheres e objetivava ter, no mínimo, 40 mulheres) e na formação técnica, capacitando as associadas em diversos assuntos, relativos à gestão (cooperativismo e produção), e relativos à corte e costura especificamente (corte-costura, moda, manutenção de máquinas, etc). A intenção era mesmo de 'profissionalizar' o grupo, tornando as costureiras donas do próprio negócio e capazes de prestar serviços de alta qualidade. Vale dizer que até então, a maioria das mulheres do grupo sabia costurar, mas não roupas de grife, com elevado 
padrão de acabamento. Aquelas que futuramente comporiam o grupo nem mesmo sabiam costurar.

O projeto foi aprovado e, finalmente, o sonho de D. Laura parecia mais próximo de se tornar realidade. O grupo que já funcionava como uma espécie de associação informal, diante do aporte de recursos obtidos pela ONG, passou a ser uma cooperativa.

O apoio financeiro de três fundações foi vital para dar início ao novo ciclo profissional das mulheres costureiras. Assim, através da ONG, um dos primeiros passos foi a reorganização do grupo. D. Laura e as cinco companheiras que restaram, e estavam juntas desde o ano de 1997, se juntaram a outras trinta e quatro mulheres que foram previamente selecionadas na comunidade de São Bartolomeu. Não era preciso ser costureira para participar da seleção Afinal, como relata uma delas, "não precisava ser costureira, mas iríamos fazer a formação em costura mesmo". Isso porque o objetivo da ONG era o de profissionalizar pessoas da comunidade e não só do grupo de costureiras. Assim, depois da seleção, todas as quarenta mulheres, mesmo as mais experientes, passaram por um curso de formação em corte e costura. Das 40 mulheres selecionadas para participarem desta primeira qualificação, apenas 20 terminaram o curso e começaram as atividades da Cooperativa.

Uma das costureiras atuantes no grupo desde o início da cooperativa comenta que o ânimo neste começo veio principalmente do forte apoio da ONG, "ela pagaria todos os custos, o espaço, [...], as capacitações, inclusive eu, e outras pessoas se formaram. $\mathrm{Na}$ época eram 35, eu sei que no final a gente acabou com 20 mulheres que levaram até o final". Após esta fase, iniciou-se o processo de constituição da identidade jurídica da cooperativa "e a gente teve todo um apoio técnico, jurídico, com um advogado, um contador, uma pessoa que era recém formada em marketing que trabalharia a parte de comercialização, e nisso o grupo estava se formando num grupo produtivo".

Muitas ações, então, foram postas em prática pela ONG que incubava o grupo. $\mathrm{O}$ intuito era o de fazer a organização funcionar. Assim, por ser uma Cooperativa, houve a necessidade de criar o Conselho de Administração, o Estatuto e o Regimento Interno. D. Laura e D. Carmen foram eleitas presidente e vice-presidente, respectivamente, da cooperativa. Não se tratou apenas de designar pessoas, mas de identificar dentro do grupo pessoas com alguma aptidão para liderança e para gerenciamento da organização. D. Carmen ficou responsável pela área administrativa da Cooperativa e participou de todo o processo da sua formalização jurídica. Isso Ihe propiciou um importante aprendizado sobre a burocracia necessária para se constituir uma personalidade jurídica. A cooperativa contava com a assistência de um advogado da ONG que liderava as ações para a regularização da organização. D. Carmen o acompanhava, tomando conhecimento das etapas percorridas e de toda documentação necessária.

\section{A costura: uma cooperativa}

No começo do ano de 2002 as perspectivas de D. Laura e do grupo de mulheres eram as melhores possíveis. Finalmente, estava criada a Cooperativa das Costureiras do Subúrbio Ferroviário de Salvador, com 'carteira de identidade' (como elas se referiam ao aparato legal de constituição de uma cooperativa). Além disso, os intentos da ONG na comunidade evidenciavam a busca pela promoção da independência do grupo de costureiras, enquanto organização; profissionalizar as mulheres e promover o empoderamento do grupo através de diversos cursos de formação.

Uma avalanche de acontecimentos tomou conta da vida das costureiras de São Bartolomeu. Elas já haviam feito o treinamento em corte e costura e a Cooperativa estava devidamente criada. A ONG alugou o espaço onde ela funcionaria, máquinas de costura industrial de diversos tipos foram adquiridas e várias oficinas foram realizadas, não só no âmbito técnico, mas também pessoal (discussões sobre trabalho em grupo; cooperativismo, ética, cidadania; autoestima, dentre outras). A preocupação era com a constituição da Cooperativa em si, e também, com a formação pessoal e profissional das mulheres que dela faziam parte.

Dois fatos valem a pena serem registrados. O primeiro, é que enquanto as vinte primeiras mulheres costureiras passavam pelos mais diversos tipos de treinamento, outras foram se incorporando ao projeto. Houve um "despertar" de novas participantes em função de tudo o que viram acontecer. Logo, a Cooperativa contava com mais de quarenta associadas. Existiam dois grupos, o das veteranas e o das novatas. E, o segundo fato, é que ainda não havia uma preocupação com os custos de tudo o que estava sendo realizado, uma vez que existia a concessão de recursos por parte das fundações que financiavam o projeto.

Com a D. Laura na liderança da produção e com a D. Carmen acompanhando parcialmente o lado da gestão, a Cooperativa começou a funcionar. Houve a realização de parcerias com importantes empresas que comercializavam roupas de grife e os primeiros contratos foram assinados. Ao mesmo tempo, ocorreu associação com instituições como SENAI, SEBRAE que ofertaram alguns cursos de capacitação. E, na opinião delas, o "melhor de tudo era que o SENAI é uma das melhores entidades na formação e a gente não tinha que ir no SENAI, o SENAI vinha até a gente pra fazer todo o processo de formação em máquinas desde manutenção preventiva de máquina até operar". Além disso, outros aspectos estimularam as mulheres a se engajarem, pois

[...] o lanche era delicioso, uma sopa deliciosa, porque tinha uma pessoa que recebia o dinheiro pra fazer, quando não era isso era cachorro-quente, que você podia comer quatro cachorro-quente. Muitas pessoas a única refeição que tinha na verdade era essa, não tomava café da manhã em casa, porque não tinham mesmo. [...]apesar da guerra em casa (enfrentando preconceitos dos maridos) de querer ser alguém na vida, de querer conquistar seu próprio espaço e chegava aqui achava aquela facilidade de ter um belo café da manhã, que realmente era! Tinha um bom café da manhã, um lanche (Entrevista, Coordenadora, out. 2011). 
Com a necessidade imperativa de atender a demanda externa, a atuação das costureiras restringiu-se, basicamente, à produção e à participação nas mais diversas oficinas ofertadas. D. Carmen, por ser responsável pela parte administrativa, escapou um pouco desta lógica e procurou acompanhar as atividades que eram realizadas por profissionais da ONG: instalação de ferramentas de gestão, organização da parte contábil, realização de parcerias com empresas de Salvador e ações de propaganda e marketing. D. Carmen tinha ainda que dar conta da sua parte no processo produtivo. Além disso, às vezes se sentia perdida em meio a tantas atividades administrativas da quais ela nunca tinha ouvido falar. As atividades de gestão em si, eram majoritariamente realizadas por especialistas contratados pela ONG (administrador, técnico em recursos humanos, contador, analista de custos, profissionais de marketing, etc).

Era assim que a Cooperativa tinha à sua disposição profissionais da ONG, que vendiam os produtos no mercado por meio de um marketing que apelava, majoritariamente, do fato de que se tratava de um projeto social, que previa empoderar mulheres costureiras de uma comunidade carente. Deste modo, várias parcerias com marcas e lojas de grife foram estabelecidas e a demanda por produção aumentava consideravelmente. Por outro lado, as costureiras tinham pouca experiência profissional e de linha de produção. Não havia a gestão da fábrica e, claro, a produção terminou tendo problemas.

Um deles se relacionava a perda de muitos produtos em função da qualidade, que não correspondia ao padrão desejado pelos clientes Apesar dos treinamentos realizados, as mulheres não adquiriram, em curto espaço de tempo, alto padrão de costura. Por exemplo, p acabamento: "Por que são peças que eles pagam caro e eles não querem nem saber, dizem: eu quero a qualidade que vocês (no caso, as lojas que contratam o serviço de costura) sempre me ofereceram. Era isso que a cooperativa não tinha, não teve o tempo hábil de preparação".

Outro problema eram os erros na confecção das roupas os quais geravam retrabalho, rotineiramente. Uma das costureiras comenta que "o produto saía da cooperativa como bom e voltava como avaliado negativo, porque tá com problema aqui, vinha marcado". Somado a isso, havia um certo desequilíbrio entre a capacidade produtiva e a demanda externa. As costureiras estavam sempre atrasadas porque não conseguiam produzir a quantidade que era demandada. Outro fator negativo, do ponto de vista das associadas, é que o aprendizado do grupo não era devidamente internalizado por falta de tempo para isso. A avalanche de acontecimentos não permitia ao grupo discutir e aprender. Por exemplo,

Logo, no ano de 2002, em meio aos diversos acontecimentos, as mulheres costureiras se viram diante de alguns dilemas. Se por um lado havia o aporte financeiro concedido pelas fundações, profissionais qualificados à disposição, parcerias com instituições e a cooperativa constituída rapidamente pela ONG; por outro ficava um sentimento de que faltava um tempo para 'digerir' tudo aquilo, compreender mais profundamente o processo produtivo e de gestão.

Vale dizer ainda que a gestão da cooperativa (setores administrativo, financeiro, pessoal, de custos, comercial, de compras), embora sendo acompanhada pela vice-presidente, era totalmente realizada por profissionais contratados pela ONG. A verba para pagamento desses profissionais estava contemplada pelas Fundações que financiavam o projeto da Cooperativa. Os custos de funcionamento da Cooperativa e dos treinamentos realizados também eram suportados pelas Fundações. Deste modo, somente os valores dos custos de produção (matéria-prima e mão-de-obra) e os salários das costureiras eram provenientes do esforço produtivo. As costureiras se sentiam angustiadas em função de não corresponderem às expectativas de mercado. Por outro lado, viviam um tempo esperado por anos a fio: finalmente elas tinham um negócio, estavam se profissionalizando, eram um grupo fortalecido e os ganhos mensais haviam melhorado.

\section{A prova e os ajustes}

O setor comercial da Cooperativa, liderado por profissionais devidamente qualificados da ONG, continuava a caminhar em velocidade acelerada. No final de 2002, já pensando em criar a própria marca de roupas da Cooperativa (havia o intento de fabricar para revender em loja própria) conseguiram estabelecer uma importante parceria com um shopping de Salvador. Embora fosse mais uma ação a gerar demanda da fábrica, se tratava de costurar roupas criadas por jovens estilistas que concorreriam a um importante prêmio do setor de moda. Seria uma ótima oportunidade para colocar a marca da Cooperativa em evidência. A partir da participação neste evento, houve, por parte do shopping, a oferta de um espaço (com os custos totalmente gratuitos) para que as roupas da Cooperativa fossem vendidas juntamente com aquelas criadas pelos estilistas vencedores. Tal convite foi aceito e, efetivamente, no ano de 2003, a loja foi inaugurada. A loja no Shopping rendeu muita visibilidade para as "Costureiras so Subúrbio Ferroviário" como eram conhecidas: "chegavam aqui e diziam: vocês conseguiram uma loja no Shopping? Vi ser uma mega inauguração! Claro! Tudo bancado, vocês precisavam ver. O buffet de primeira qualidade [...]... Era uma mídia de dar inveja em outros empresários [...] D. Laura já tinha dado entrevista desde a TV Bahia até TVE! E na rádio".

Os funcionários contratados para trabalharem na loja do shopping foram selecionados no mercado de trabalho e não provinham da comunidade. Além disso, a Cooperativa arcava com os custos de manutenção da loja, sobretudo os salários dos vendedores, e outros custos de funcionamento do espaço.

A partir do final de 2003 a Cooperativa passou a ter que atender a demanda dos clientes fixos e, além disso, fabricar as roupas que abasteceriam a loja do shopping. Os problemas anteriores continuavam. Embora as costureiras estivessem motivadas e quisessem muito o crescimento da produção, não tinham condições 
materiais para acompanhar a demanda e a qualidade exigida por alguns clientes em suas roupas. A solução, então, foi adquirir mais máquinas, selecionar e capacitar mais mulheres em um espaço de tempo relativamente curto. Apesar dos vários treinamentos na área de fabricação, muito do que era feito se baseava na experiência das mulheres. Isso fazia com que a produção fosse pequena e houvesse desperdício de matéria-prima, além de comprometer a qualidade dos produtos fabricados. Por outro lado, também não havia na Cooperativa quem criasse as roupas da marca própria. Deste modo, terminaram se equivocando quanto à produção destinada à loja e os produtos acabaram encalhados no estoque. De acordo com D. Carmen, "não foi feito uma pesquisa de mercado [...]. O que é que a gente vai vender? Nós vamos vender um produto pra quem? Quer dizer, saía roupas aqui que eram totalmente voltadas para senhoras [...] a gente já sabia que o Shopping era frequentado muito por jovens, por estudantes mesmo..."

Com as mercadorias encalhadas, os custos da loja foram cobertos pelos demais ganhos obtidos pela Cooperativa. Então, as costureiras passaram a arcar com os prejuízos da loja com seus próprios ganhos mensais. Neste caso específico, a ONG, com os seus técnicos qualificados, não conseguiu alavancar os negócios e a loja no shopping, no final de 2005, foi fechada por decisão das próprias cooperadas, diante dos custos elevados e da 'correria' para dar conta da demanda por produção. Se, por um lado, a abertura da loja se configurou como uma tentativa de consolidar a marca da Cooperativa no mercado e obter independência produtiva e comercial. Por outro lado, o seu fechamento representou o momento em que as costureiras, depois de anos, se pronunciaram a respeito de algo com o qual não concordavam.

\section{O acabamento}

Sem a loja no shopping, as mulheres resolveram voltar o olhar para a produção conforme os moldes antigos: atendendo pedidos de clientes, costurando para lojas de grife. No final de 2004 uma boa notícia alegrou o grupo de costureiras. A ONG conseguiu, via convênio com o Banco Mundial, a verba para comprar a sede própria da Cooperativa. Adquiriram o imóvel e fizeram uma reforma que foi totalmente concluída em 2006. O espaço foi totalmente equipado com máquinas, computadores, móveis e demais instrumentos necessários à confecção de roupas e administração do negócio. No térreo do prédio da Cooperativa foi construída uma loja com o objetivo de comercializar roupas com uma marca própria.

Até o ano de 2007, cinco anos após a sua constituição, o funcionamento da Cooperativa seguia como antes: as Fundações suportavam os custos principais, os técnicos da ONG continuavam à frente das atividades de gestão com D. Carmem acompanhando algumas delas, as costureiras tentavam atender a demanda por produtos, havia muito retrabalho e as líderes continuavam as mesmas.
As costureiras, de maneira geral, não gostavam (ou não se sentiam a vontade) de manifestar os seus pensamentos e angústias. Sempre esperavam que atitudes assim partissem da D. Laura ou da D. Carmen. Porém, embora não houvesse manifestação coletiva por parte do grupo, pairava uma certa insatisfação. No final do ano de 2007, alguns questionamentos começaram a surgir dentro do próprio grupo de costureiras, e muitas desistiram de continuar na Cooperativa e buscaram trabalho no mercado. Os ganhos continuavam insatisfatórios e a rotatividade de costureiras prejudicava ainda mais o processo produtivo.

Nesse momento, um grupo de mulheres da Cooperativa passou a questionar o modo como as coisas estavam sendo conduzidas desde o início. Pensavam que tinham de se tornar independentes da ONG e do financiamento das Fundações e que deveriam buscar a produção independente, com qualidade, de modo a terem condições de criar, produzir e escoar os próprios produtos. Começaram a pensar, ainda, na necessidade de terem ganhos maiores e, de certa forma, estáveis. Do jeito que as coisas iam, apesar dos já transcorridos cinco anos, se preocupavam com o fato de estarem praticamente 'engatinhando' do ponto de vista da gestão do negócio. Outro ponto de divergências estava relacionado ao modo como D. Carmen liderava o grupo. Embora fosse reconhecida como líder e fosse respeitada pelo grupo, ela tinha dificuldades de implementar as técnicas de produção e orientava os trabalhos na fábrica com base na sua experiência anterior, de excelente costureira.

Os questionamentos do grupo juntaram-se ao fato de que as Fundações que forneciam o aporte de recursos para a Cooperativa reduziram consideravelmente o apoio ao projeto. Deste modo, já não havia mais como pagar por tantas consultorias que a ONG oferecia e, tampouco, cobrir os custos administrativos e de produção. Além disso, dentro do grupo havia uma percepção de que a ONG já havia cumprido o seu papel uma vez que o negócio estava criado e estruturado. Era preciso dar conta de seguir adiante com esforço próprio.

A partir do ano de 2008, a atuação da ONG na Cooperativa já não era tão forte. As próprias costureiras começaram a buscar a independência para o negócio; inclusive $D$. Carmen que procurou dominar melhor a parte de gestão. A intenção das cooperadas era continuar a produção dentro do padrão que alcançaram. Para tanto, mantiveram as parcerias e seguiram adiante, produzindo peças de acordo com a encomenda dos clientes. Entretanto, o problema dos ganhos continuava. $\mathrm{O}$ retorno era baixo e afetava a rotatividades das costureiras.

Em 2009 houve uma nova tentativa de ampliar o grupo de profissionais, sem grande sucesso. Embora um novo treinamento tenha sido ofertado, poucas pessoas concluíram. Com isso, apenas mais cinco mulheres aderiram ao projeto e, então, o grupo contava com 25 costureiras. Já mais distante da influência da ONG, o grupo de costureiras aprofundou também as discussões em torno de duas questões: a) era preciso eleger novas lideranças; b) havia 
necessidade de colocar em prática as técnicas ensinadas nos diversos treinamentos que fizeram e realmente transformar 0 processo produtivo. Este era um esforço claro para alavancar os negócios e fazer o faturamento da Cooperativa aumentar, promovendo a sua autonomia e sustentabilidade econômicofinanceira. Diante disso, uma nova eleição foi feita no começo do ano de 2009 quando D. Carmen tornou-se presidente da Cooperativa e D. Laura passou a compor o Conselho Administrativo. Não obstante a alteração de papeis formais, o processo de tomada decisão permanecia sob a responsabilidade das mesmas pessoas.

Durante o decorrer do ano de 2009 a Cooperativa contou com um grupo de mais ou menos 25 costureiras e as atividades produtivas não mudaram. Se, por um lado, a produção não mudou muito, por outro observou-se uma grande diferença na gestão da Cooperativa. Com o término dos projetos e retirada do aporte financeiro das Fundações, os profissionais enviados pela ONG para criar e gerenciar a Cooperativa não atuavam mais na gestão da organização. Dessa forma, o grupo de mulheres, organizadas em cooperativa, se tornou independente. A partir de 2009 já não tinham quem fizesse o marketing, quem fizesse a captação de clientes, quem cuidasse da contabilidade, do controle dos custos e da parte administrativo-financeira da organização. Além disso, os custos antes suportados pelas Fundações agora eram da Cooperativa e retirados do faturamento (água, energia elétrica, salários, matériaprima, etc).

$\mathrm{Na}$ tentativa de fazer com que a Cooperativa continuasse rentável e autônoma, as costureiras decidiram que a produção das peças passaria a ser feita por fases, seguindo as recomendações técnicas. Decidiu-se também atender uma demanda por uma produção não tão sofisticada - com baixo grau de exigência no acabamento. A confecção passou a ser centrada em fardamentos e bolsas, peças mais rústicas e, portanto, mais fáceis de serem confeccionadas pelas costureiras que não conseguiram alcançar, na costura, o alto padrão de qualidade requerido pelas lojas de grife. $O$ controle dos custos e da produção individual de cada uma passou a ser feito de maneira manuscrita, pelas próprias costureiras. Enfim, elas tentaram colocar em prática, com as ferramentas que tinham, os conhecimentos adquiridos ao longo dos anos em que receberam consultorias especializadas. No entanto, com o passar do tempo, não houve crescimento da produção, tampouco dos ganhos. Para piorar a situação, alguns clientes deixaram a Cooperativa.

No começo do ano de 2010, D. Laura, uma referencia importante para o grupo, deixou a Cooperativa por alguns problemas pessoais.

\footnotetext{
' O SENAI e o SEBRAE são organizações que compõem o denominado sistema ' $S$ ' no Brasil. As organizações que compõem este sistema se intencional promover educação profissional para o setor produtivo no país como a indústria, a agricultura, o transporte etc. As instituições do Sistema S não são públicas, mas recebem subsídios do governo. No caso do SENAI (http://www.senai.br) - Serviço Nacional de Aprendizagem na Indústria, este se preocupa com a educação profissional e a prestação de serviços de assistência técnica e tecnológica à indústria. O SEBRAE
}

A sua saída foi bastante sentida porque não era somente uma líder que se afastava, mas também alguém que tinha reconhecida competência no ofício de costurar. D. Laura, embora não tivesse tido êxito em colocar as técnicas produtivas modernas em prática, entendia de costura como ninguém e era capaz de dirimir as dúvidas e ensinar o 'modo de fazer' sempre que necessário.

Os anos de 2010 e 2011 transcorreram elucidando as mesmas dificuldades antes percebidas. Em virtude do baixo faturamento, várias costureiras deixaram a Cooperativa e o grupo ficou reduzido a dez mulheres. Os clientes também já eram poucos, cerca de três empresas mantinham contratos com a Cooperativa para a confecção de fardamentos. Com o número reduzido de profissionais, a carga de trabalho individual aumentou e o faturamento continuou baixo. Além de adquirir a matéria-prima, todos os demais gastos eram totalmente suportados pelo faturamento próprio. Com isso, em certos meses cada cooperada recebia menos do que um salário mínimo depois de trabalhar mais de oito horas diárias, de segunda a sábado.

Atualmente, o desânimo é visível nos olhos das cooperadas que dependem da sua própria capacidade de produção e de gestão. D. Carmen parece refletir essa sensação: ela se divide entre tarefas de gestão, produção e vendas: ajuda na costura, tenta amealhar novos clientes, ensina técnicas de costura para as companheiras, tenta criar mecanismos de controle de custos; realiza atividades administrativas e de gestão da organização. A sede da Cooperativa continua lá, com a estrutura propícia a uma significativa produção, mas relativamente ociosa pelos problemas de gestão e de recursos.

A esta altura, D. Carmen já demonstra dificuldades em dar conta de equacionar todos os problemas e suas forças para continuar a luta estão bastante reduzidas. Catorze anos depois dos sonhos e desencantos de D. Laura e do primeiro grupo de costureiras, D. Carmen tem a impressão de que o tempo passou, alguma coisa aconteceu, mas o ponto de partida é o mesmo do de catorze anos atrás. Seria o momento de recomeçar? Como?

\section{Questões sugeridas para discussão e análise:}

a) Identifique e sistematize os problemas enfrentados pelo grupo de costureiras antes, durante e depois do processo de intervenção da ONG.

b) Analise o processo de incubação da cooperativa pela ONG procurando destacar os aspectos que podem estar relacionados com os pontos frágeis da cooperativa hoje.

c) Discuta ações e estratégias de gestão simples para que a cooperativa enfrente os desafios que enfrenta hoje para que ela se mantenha e se desenvolva no mercado.

d) Esboce uma proposta metodológica de incubação diferenciada para o caso da Cooperativa de Costureiras, que considere as especificidades do território.

(http://www.sebrae.com.br/) - Serviço Brasileiro de Apoio às Pequenas e Médias Empresas congrega programas e projetos que visam apoiar 0 desenvolvimento de pequenas e médias empresas 